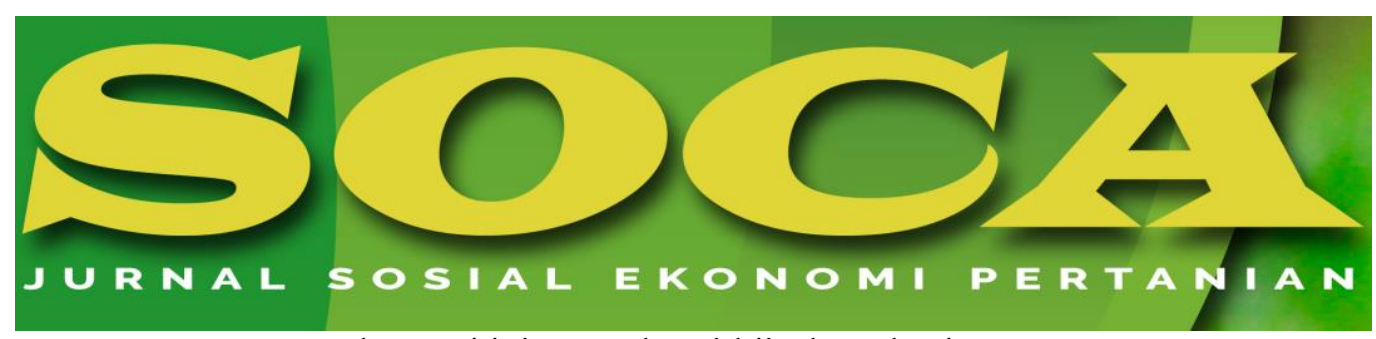

https://ojs.unud.ac.id/index.php/soca

\title{
The Dynamics of Horticultural Farmers Groups in Malang Regency and Batu City
}

\author{
Ary Bakhtiar, Rahmad Pulung Sudibyo, Indriani and Wahid Muhammad Shodiq \\ Muhammadiyah Malang University, Malang, East Java \\ Email: arybakhtiar92@yahoo.co.id,rahmad_sudibyo@yahoo.co.id, \\ indrianiusman432@gmail.com and wahidmuhshodiq@gmail.com \\ Mobile: 082140841550, 08123364630, 082331442430 and 082210776874
}

Submitted: December 30th, 2019; Revised: April 22 ${ }^{\text {nd }}$, 2020; Accepted: May 28th 2020

\begin{tabular}{l}
\hline Keywords: \\
Horticultural; \\
Farmers \\
Group; \\
Dynamics \\
\hline
\end{tabular}

\begin{abstract}
The development in the agricultural sector required an increase in human resource capacity. The special effort can be in the form of training and skills in processing agricultural products. The research aim was to analyze the factors that influence the dynamics of horticultural farmers groups, and assessed the level of group dynamics and the independence of horticultural farmer group members. The determination of the location of the research was performed by using a qualitative descriptive method, which was performed in two locations, which were Pujon Sub-district, Malang Regency and Batu City. The research was conducted from October to November 2019. The analysis used was descriptive analysis to describe the level of group dynamics in the two regions which were Pujon Sub-district Malang Regency and Batu City. The dynamics level of horticultural farmers in each region was categorized as low $(\leq 20 \%)$, moderate $(20.1 \%-40 \%)$, normal $(40.1 \%-60 \%)$, high $(60.1 \%-80.00 \%)$ and very high $(\geq 80 \%)$. The results showed that the dynamics value of the horticultural group in Malang City was included in the high category, which was $77.18 \%$. While the value of group dynamics in Malang Subdistrict of Pujon was $77.08 \%$ and in Batu City was $77.27 \%$, both regions were included in the high category.
\end{abstract}

How to Cite (APA 6th Style):

Bakhtiar, A., Sudibyo, R. P., Indriani, \& Shodiq, W. M. (2020). The Dynamics of Horticultural Farmers Groups in Malang Regency and Batu City. SOCA: Jurnal Sosial Ekonomi Pertanian, 14(3), 476-484.

https://doi.org/https://doi.org/10.24843/SOCA.2020.v14.i03.p09 


\section{INTRODUCTION}

The development of the agricultural sector required an increased in human resource capacity. The efforts to improve the quality of human resources both in the understanding of technology in agriculture and its application in the field certainly required special efforts. The special effort can be in the form of training and skills in processing agricultural products. Of course, this step required a long time, but thus efforts to increase production and quality would be an urgent problem. The strategies that can be used to anticipate this were through farmer group institutionalization.

Farmer groups were one of the institutions that grew and develop in the farming community. The farmer group institutionalization was formed because there were similarities and goals of each member. This was in line with the statement of Nuryanti \& Swastika (2011) which stated that farmer groups were formed to solve problems and obstacles in the field that cannot be solved individually. The same thing was also explained by Sadjad (2010) in Nuryanti \& Swastika (2011) which revealed that the motivation for the formation of farmer groups was the process of embodying agriculture towards a better direction. Many farmer groups contributed and gave benefit to all the members. The activities that can be done together will make it more efficient and efficient for farmers. Thus, the goal of improving the quality and production of farmers can be achieved.

Horticultural farmer institutionalization was an inseparable sub-part of the farmer group. Horticultural farmer groups have specific production in the field of horticulture only. Over time, farmer institutionalization continued to improve both in terms of governance and improvement of human resources, because one of the spearhead of the success from the goals of this group was its human resource capabilities, the more qualified its human resources, it can be said that the farmer group was already in the empower category.

Horticultural farmer groups can be said to be empower if the level of their living rates have increased, both in the form of income and daily needs can be fulfilled. One of the basic needs for farmers was clothing, food and housing. As for some additional other needs that were beyond basic needs. If the basic needs have been fulfilled then all activities whether work activities in the field of farming (main) can goes well, and vice versa.

Literally, a group was a set of two or more people who were joined in an association that has similarities and interacts through certain structures/patterns in an effort to achieve common goals within a certain period of time, Slamet (2002). This definition was in line with Iver and Page in Mardikanto (1993), who expressed that groups were a set of people who stayed and lived together to form reciprocal relationships and influenced each other in the social life of society.

The farmer groups were formed on the basis of same principles to the environment (socio-economic) in an effort to achieve common goals and improved the conditions of group members consisting of farmers, breeders to planters (Indonesian Minister of Agriculture, 2016).

Farmer groups were included in non-formal organizations that grew and developed using democratic principles (from, by and for the people). But in the functions, duties, authorities and responsibilities of the members in achieving the goals that have been set together, Amir (2009) explained that group dynamics were actions taken by members in a group. The results showed that one way to solve 
problems in an organization was the courage to discuss and discussing problems that rose so it did not disturb the harmony of an organization. These actions were chosen so that the goals that have been set together can be achieved immediately.

This study aimed to, 1) Analyze the factors that influence the dynamics of horticultural farmers groups, and 2) study the level of group dynamics and independence of horticultural farmer group members.

\section{RESEARCH METHODS}

\section{Place and time of the Research}

Pujon Sub-district, Malang Regency and Batu City were chosen as the location of the research performed in October to November 2019. Both regions were chosen because many farmers worked on horticultural commodities. Especially in the Pujon Sub-district area there was the Mantung Agribusiness sub-terminal, one of the functions as a farmer's bridge in selling their agricultural commodities that they endeavored through an auction mechanism at prices on farmers' side.

\section{Types and Methods of the Research}

The study used qualitative descriptive research that will describe the object of research based on facts that occurred in the field. The research method used the survey method which was performed in a part of the population and was considered to be able to represent the population to provide an overview of the research.

\section{The Samples Taken and Collected}

The research sample was the core management in a farmer group consisting of the chairman, secretary, treasurer and members. From each farmer group will be taken 5 people who will be used as a sample of this research. Determination of the sample was using purposive sampling method. Meanwhile, data collection was using questionnaires, interviews, observation and documentation.

\section{Data analysis}

Descriptive analysis was intended to describe the level of group dynamics in the two regions, which were Pujon Sub-district, Malang Regency and Batu City. The dynamics level of horticultural farmers in each region was categorized as low $(\leq 20 \%)$, moderate $(20.1 \%-40 \%)$, normal $(40.1 \%-60 \%)$, high $(60.1 \%-80.00 \%)$ and very high $(\geq 80 \%)$.

\section{RESULTS AND DISCUSSION \\ Participant's Characteristic}

The recapitulation results of respondent data which obtained from questionnaires distribution were presented in table 1 as follows.

Table 1. Respondent Characteristics

\begin{tabular}{cccc}
\hline No & Respondent Based on Age & $\begin{array}{c}\text { Frequency } \\
\text { (People) }\end{array}$ & $\begin{array}{c}\text { Percentage } \\
\text { (\%) }\end{array}$ \\
\hline 1 & (Years O1d) & 5 & 12,20 \\
2 & $20-29$ & 16 & 39,02 \\
3 & $30-39$ & 18 & 43,90 \\
4 & $40-49$ & 1 & 2,44 \\
5 & $50-59$ & 1 & 2,44
\end{tabular}


Total

Gender

8

9

9

Male

Female

Total

Education Level

$\begin{array}{cc}10 & \text { Not Graduated From Elementary School } \\ 11 & \text { Elementary School } \\ 12 & \text { Junior High School } \\ 13 & \text { Senior/Vocational High School } \\ 14 & \text { Bachelor Degree } \\ 15 & \text { Master Degree } \\ & \text { Total }\end{array}$

Source: primary data (processed), 2019

Table 1 showed that the total of respondents were dominate by age range of 40-49 years old as of 18 people $(43,90 \%)$, male as of 24 people $(58,54 \%)$ and education level of Senior/Vocational High School as of 16 people $(39,02 \%)$. The characteristic respondents on the age range was the same with the research result of (Haqiqiansyah et al, 2016) but inversely proportional on the education level.

\section{The Group Dynamics}

Amir (2009) explained that the group dynamics was actions that performed by the group members. The elements forming the group dynamics in this research was purpose, structure, function, coaching, cohesiveness, atmosphere, pressure, group effectiveness and member religiosity. The following was the group dynamics value that presented in table 2 .

Table 2. Calculation of Group Dynamics Level

\begin{tabular}{lccc}
\hline \multirow{2}{*}{ Group Dynamics Element } & \multicolumn{3}{c}{ Value (\%) } \\
\cline { 2 - 4 } & $\begin{array}{c}\text { Pujon Sub- } \\
\text { District }\end{array}$ & Batu City & Average \\
\hline Group Purpose & $70,50 \%$ & $74,59 \%$ & $72,54 \%$ \\
Group Structure & $69,03 \%$ & $64,90 \%$ & $66,96 \%$ \\
Group Function and Purpose & $73,33 \%$ & $74,12 \%$ & $73,73 \%$ \\
Group Coaching & $70,83 \%$ & $79,53 \%$ & $75,18 \%$ \\
Group Cohesiveness & $84,67 \%$ & $81,65 \%$ & $83,16 \%$ \\
Group Atmosphere & $75,63 \%$ & $74,71 \%$ & $75,17 \%$ \\
Group Pressure & $70,83 \%$ & $65,59 \%$ & $68,21 \%$ \\
Group Effectiveness & $84,17 \%$ & $87,45 \%$ & $85,81 \%$ \\
Religiosity & $94,72 \%$ & $92,94 \%$ & $93,83 \%$ \\
\hline \multicolumn{1}{c}{ Dynamics Element Value } & $77,08 \%$ & $77,27 \%$ & $77,18 \%$ \\
\hline
\end{tabular}

Source: Processed Primary Data, Year 2019

Table 2 explained that the dynamics value of the horticulture group in Malang Raya was in the high category, which was $77.18 \%$. While the value of group dynamics 
in Pujon Sub-District Malang Regency was $77.08 \%$ and in Batu City was $77.27 \%$, both regions were included in the high category.

\section{Group Purpose}

Group purposes were targets, processes and descriptions of something that was expected to be achieved by the group (Sirojudin, 2017). The ability to move all members in behaving and performing tasks in an effort to achieve the group purposes was the responsibility of the leader. Therefore, efforts needed so that all members understand the group's purposes. The group purposes that have been set need to be assessed to know how much the group purposes were truly understood and internalized by all members (Andarwati et al, 2012). The categories used in this research were: 1) Did the work with full responsibilities, 2) Worked always oriented to group purposes, 3) Always coordinated with group members in performing all the work, 4) Worked completely without seeing the group's guidelines and targets, and 5 ) Worked must be with the encouragement of others.

Based on table 2, the average value of groups in the two regions studied for the value of group dynamics in the group structure was included in the high category, which was $72.54 \%$. Farmer groups in the Pujon Sub-District had a high percentage of $70.50 \%$, while the farmer groups in the City of Batu have a high percentage of $74.59 \%$.

\section{Group Structure}

Andarwati et al., (2012) group structure was a regular pattern in the relationship between individuals and then between groups that can simultaneously describe the level/position and the role of each member in an effort to achieve the targets set in a group. The categories used in this research were: 1) Performed tasks and functions according to the organizational structure and command lines in the group, 2) Utilized office facilities for coordination meetings between members, 3) Always honoring and respecting the leaders' decisions, 4) worked waiting for command from leader, and 5) Did tasks that were not my responsibility.

The average value of the groups in table 2 in the two regions was examined in terms of the group structure included in the high category, which was $66.96 \%$. Farmer groups in the Pujon Sub-District had a high percentage of $69.03 \%$, while the farmer groups in the City of Batu have a high percentage of $64.90 \%$.

\section{Group Function}

Functions and purposes in a group were things that must be done in order to achieve a goal that has been targeted in performing its function. There were several functions in a group that must be performed one of it was the function of spreading information, the function of organizing a collaboration, the function of inviting participation and the function of explaining an allocation of jobs within each of the positions (Andarwati et al., 2012). The categories used in this research were: 1) Sometimes made my own decisions without group agreement, 2) My decisions were always valued by other members, 3) Always coordinated with the leaders and group members, 4) Enjoy worked in teams, 5) Enjoy worked with many people because it will produce many ideas, 6) Worked, I depend myself on others, 7) Always explained my statement again, if something was not understood, 8) The leader of my group 
always assigned tasks that fit my ability, and 9 ) Sometimes I did not understand my role in the group.

The average group value in table 2 in both regions in the group function element was included in the high category, which was $73.73 \%$. Farmer groups in the Pujon Sub-District had a high percentage of $73.33 \%$, while the farmer groups in the Batu City area had a high percentage of $74.12 \%$. This means that all indicators that asked were responded well by respondents. One vital aspect was related to leadership, because the organization will went and be organized if it was led by leaders who understand well what was needed and required by the organization. These results were in line with (Pertiwi, 2013) which stated that leaders must be able to bring the groups that they lead to achieve their purposes, improve communication, motivate farmers, facilitate agricultural infrastructure, and solve problems.

\section{Group Coaching}

The coached of farmer groups in the farmer groups dynamics in the Pujon Sub-District and Batu City can be measured by the participation of farmer group members. Coaching required a facility to improve performance in the job allocation process (Andarwati et al., 2012). Sirojudin (2017) mentioned the awareness of members to remain in the group will stay if there was coaching. The categories used in this research were: 1) Every problem was always overcome with discussion, 2) Exchanged thoughts, ideas and notions was better than worked by yourself, 3) Secretariat was used as a facility of exchanging opinions and discussion, 4) Every complaint at work were always discussed, and 5) The concept of group coaching that performed was not sustainable.

The average group value in table 2 in the two regions in the group coaching element was in the high category, which was $75.18 \%$. Farmer groups in the Pujon Sub-Distric had a high percentage of $70.83 \%$, while the farmers group in the Batu City had a high percentage of $79.53 \%$.

\section{Group Cohesiveness}

Group cohesiveness was the level of feeling to settle in the group. A cohesive group will pay more attention to the welfare of members, purposes, and encouraged members to participate in group activities so that it can be concluded that group cohesiveness affected group behavior (Sirojudin, 2017). The categories used in this research were: 1) Always maintaining group integrity, especially if there is a misunderstanding, 2) Always seeking help if you encounter difficulties, 3) Feel the same rights and obligations within the group, 4) Leaders coordinated and cooperated with their members, and 5) The group leader participated in the work.

The average value of the groups in the two regions in the group cohesiveness element was in the high category, which was $83.16 \%$. Farmer groups in the Pujon Sub-District had a high percentage of $84.67 \%$, while the farmer groups in the Batu City had a high percentage of $81.65 \%$.

\section{Group Atmosphere}

Group atmosphere was considered as an element in causing reactions among members in the group. The interesting groups were groups where the members feel welcomed and valued and full of brotherhood. The atmosphere of the group contained 
the values of morality, attitudes and feelings that were generally found in groups (Sirojudin, 2017). The atmosphere can describe solidarity with group members to other group members through meetings in each activity. The categories used in this research were: 1) Serious but relaxed work (high familial/familial nature) 2) If a friend has difficulties I always help him, 3) Appreciated other group activities, and 4) prioritized personal interests rather than common interest.

The average value of groups in the two regions in the group atmosphere element was included in the high category, which was $75.17 \%$. Farmer groups in the Pujon Sub-District had a high percentage of $75.63 \%$, while the farmer groups in the Batu City had a high percentage of $74.71 \%$.

\section{Group Pressure}

Sirojudin (2017) group pressure was considered as something that gave encourage to the urge to do something in an effort to achieve group purposes. One of group pressure was the existence of reinforcement and punishment which given to members for their actions. Group pressure was given to members with the intention to minimize the differences that rose in the group because of differences in the members' desires and performed by certain people who were more dominant. The categories used in this research were: 1) Always accepting criticism from other parties, 2) If criticized by others, I am more and more enthusiastic about developing ideas, 3) Accepting progress every time and competition as opportunities to develop ideas, and 4) If I getting criticized, my work motivation was decreased.

The average value of the groups in the two regions in the group pressure element was in the high category, which was $68.21 \%$. Farmer groups in the Pujon Sub-District had a high percentage of $70.83 \%$, while the farmer groups in the Batu City area had a high percentage of $65.59 \%$.

\section{Group Effectiveness}

Group effectiveness was a success that has been achieved in the group, while it can be seen in the achievement of any circumstances or changes that occurred (Andarwati et al., 2012). The categories used in this research were: 1) Always attemped to make improvements and increased productivity, 2) We always value every product produced by each group member, and 3) We received rewards for achievement.

The average value of the groups in the two regions was examined in terms of the group effectiveness included in the high category, which was $85.81 \%$. Farmer groups in the Pujon Sub-District had a high percentage of $84.17 \%$, while the farmers group in the Batu City had a high percentage of $87.45 \%$.

\section{Group Religiosity}

Religiosity was a complex system of beliefs, faiths and attitudes and ceremonies that connected individuals with one being or to something that was divine (Fitriani, 2016). The categories used in this research were: 1) I actively participated in religious organization activities, 2) Believe in maintaining friendship among group members can build a sense of kinship, and 3) Believe that working earnestly in a group will get rewarded. 
The average value of the groups in the two regions in terms of religiosity was included in the high category, which was $93.83 \%$. Farmer groups in the Pujon SubDistrict had a high percentage of $94.72 \%$, while the farmer groups in the Batu City had a high percentage of $92.94 \%$. This means that one's religiosity in a group still influenced one's behavior in social life including organizing. These results were in line with (Affandy, 2017) which stated that the nature of religious teachings was able to reach the whole of human life, because humans have an individual or group mental dimension.

All research variables showed high average scores. This means that the variables which studied were able to influence the dynamics in a group. These results were in line with (Falo, 2016) which stated that group dynamics were influenced by goals, structure, functions, coaching, cohesiveness, atmosphere, effectiveness and pressure in an organization. The similarity between the previous research and the research that has been done was, there was a variable that was used, but the research in this study added a religiosity variable that aimed to determine whether it affects the other variables. The role of farmer groups in the application of technology aimed at increasing agricultural output, so that farmers improved the performance and cohesiveness between groups; Whereas, the recent study was more about the group dynamics in Pujon Sub-district, Malang City and Batu City. The difference between previous research and research that has been done was found in the role of farmer groups where the research that conducted examined group goals, group structure, group functions, group cohesiveness, group effectiveness, group Religiosity and group atmosphere.

\section{CONCLUSION}

The value of horticulture group dynamics in Malang Raya was in the high category, which was $77.18 \%$. The elements that forming the group dynamics in this research were group goals, group structure, group functions and goals, group coaching, group cohesiveness, group atmosphere, group pressure, group effectiveness and religiosity.

\section{RECOMMENDATION}

The recommendations in this research were as follows: For horticultural farmer groups in the research area was expected to make the group structure more clear and structured so that each member was able to understand their duties in the group. In addition, it was expected not to make excessive group pressure so that group goals that have been designed can be realized in accordance with predetermined targets. The next research was expected to be able to develop more research variables and research objects.

\section{REFERENCES}

Affandy, S. (2017). Penanaman Nilai-Nilai Kearifan Lokal dalam Meningkatkan Perilaku Keberagaman Peserta Didik. Jurnal Atthulab, 2(2), 1438.

Amir, A. M. (2009). Penerapan Dinamika Kelompok. Jurnal Academica, I, 120-130.

Andarwati, S., Guntoro, B., Haryadi, F. T., \& Sulastri, E. (2012). Dinamika Kelompok 
Peternak Sapi Potong Binaan Universitas Gadjah Mada di Propinsi Daerah Istimewa Istimewa Yogyakarta. Jurnal Penelitian Imu Peternakan, 10(1), 29-46.

Falo, M. (2016). Kajian Dinamika Kelompok Tani Usaha Ternak Sapi Potong di Kelompok Tani Nekmese Desa Manusasi Kecamatan Miomaffo Barat. Jurnal Agribisnis Lahan Kering, 1(2502), 15-18.

Fitriani, A. (2016). Peran Religiusitas Dalam Meningkatkan Psychological Well Being. Jurnal Al-AdYaNi, XI(1). Retrieved from https: / / media.neliti.com/media/ publications / 177730-ID-peran-religiusitasdalam-meningkatkan-ps.pdf

Haqiqiansyah, G., Fidhiani, D. D., \& Sulistianto, E. (2016). Analisis Dinamika Kelompok Tani Nelayan di Pesisir Kota Bontang. Jurnal Agriekonomika, 5(1), 31-40.

Mardikanto, T. (1993). Penyuluhan Pembangunan Pertanian. Surakarta: Sebelas Maret University Press.

Mentan_RI. (2016). Peraturan Menteri Pertanian Republik Indonesia tentang Pembinaan Kelembagaan Petani. Jakarta. Retrieved from http://perundangan.pertanian.go.id/admin/p_mentan/Permentan 67-2016 Pembinaan Kelembagaan Petani.pdf

Nuryanti, S., \& Swastika, D. K. S. (2011). Peran Kelompok Tani dalam Penerapan Teknologi Pertanian. Jurnal Forum Penelitian Agro Ekonomi, 29(2), 115-128.

Pertiwi, P. R. (2013). Peran Kepemimpinan Kontak Tani Dalam Proses Difusi Inovasi Teknologi Pengelolaan Tanaman dan Sumberdaya Terpadu Padi. Jurnal Matematika, Sains Dan Teknologi, 13(1), 51-63.

Sirojudin, M. K. (2017). Konsep Kelompok. Retrieved December 20, 2019, from http: / / file.upi.edu/Direktori/FIP/JUR._PEND._LUAR_SEKOLAH / 194505031 971091-MUHAMMAD_KOSIM_SIRODJUDIN/KONSEP_KELOMPOKx.pdf

Slamet, S. (2002). Kumpulan Bahan Mata Kuliah Organisasi dan Kepemimpinan. Bogor: Institute Pertanian Bogor. 